Articles by René Lemarchand, James C. Scott, Isaac Kramnick, Arnold Kanter, Gordon S. Black, Thomas W. Casstevens

\title{
Robert Axelrod
}

Where the Votes Come From: An Analysis of Electoral Coalitions, 1952-1968

\section{Austin Ranney \\ Turnout and Representation in Presidential Primary Elections}

\author{
B. Michael Frolic \\ Decision Making in Soviet Cities
}

Robert J. Lieber

Interest Groups and Political Integration: British Entry Into Europe

Robert E. Lane

APSA Presidential Address: To Nurture a Discipline

Published Quarterly by

The American Political Science Association

Vol. LXVI March 1972 No. 1 


\section{NEW \\ from HARPER \& ROW}

\section{ACTION AND ORGANIZATION \\ An Introduction to Contemporary Political Science}

\section{ROBERT C. BONE}

Balanced between traditional and behavioral approaches, this book provides an introduction to political science in terms of its contemporary vocabulary and analytical concepts. It systematically unravels the intricate relationship of "action" and "organization," with underlying emphasis on the role of cultural influences. Instructor's Manual. March, 1972. Paper. 470 pp.; $\$ 6.95$.

\section{OUTSIDE, LOOKING IN \\ Critiques of American Policies and Institutions, Left and Right DOROTHY BUCKTON JAMES, Editor}

Twenty-three critiques of American policies and institutions from the ideological left and right present the basic controversies and problems of the American system within an interesting and informative framework designed to provoke student thought and understanding. Included are sixteen original papers. Among the contributors: Morgenthau, Viereck, Kariel, van der Haag, Frankel, Barnet, Banfield, Lumar, and Rothbard. Introduction by the editor. March, 1972. Paper. Tentative: 448 pp.; $\$ 3.95$.

\section{POLITICAL CONTINUTTY AND CHANGE, Revised Edition \\ PETER H. MERKL}

This new edition, geared to the changing political concerns of students, has been revised to reflect the major upheavals in politics and political science which have occurred since the book first appeared. It remains a comprehensive, general introduction to political theory and comparative government which approaches its subject from a topical or analytical point of view. The book's length and objective approach assure flexibility. Instructor's Manual. March, 1972. Paper. 516 pp.; $\$ 7.00$.

\section{STABILITY AND CHANGE IN CONGRESS}

BARBARA HINCKLEY

1971. Paper. 216 pp.; $\$ 3.50$.
CONDUCTING POLITICAL RESEARCH

E. TERRENCE JONES

1971. Paper. 221 pp.; $\$ 6.00$.

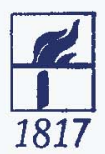

HARPER \& ROW, Publishers, Inc. 49 East 33d Street, New York 10016

For more information write Dept. 275 (G). 


\title{
The American Political Science Review
}

\author{
Vol. LXVI
}

March 1972

No. 1

\section{CONTENTS}

11 Where the Votes Come From: An Analysis of Electoral Coalitions, 1952-1968

Robert Axelrod

21 Turnout and Representation in Presidential Primary Elections Austin Ranney

38 Decision Making in Soviet Cities

B. Michael Frolic

53 Interest Groups and Political Integration: British Entry Into Europe

Robert J. Lieber

68 Political Clientelism and Ethnicity in Tropical Africa: Competing Solidarities in Nation-Building

René Lemarchand

91 Patron-Client Politics and Political Change in Southeast Asia

James C. Scott

114 On Anarchism and the Real World: William Godwin and Radical England

Isaac Kramnick

129 Congress and the Defense Budget: 1960-1970

Arnold Kanter

144. A Theory of Political Ambition: Career Choices and the Role of Structural Incentives

Gordon S. Black

160 The Committee Function: An Influence Equation

Thomas W. Casstevens

164 APSA Presidential Address: To Nurture a Discipline

Robert E. Lane

183 Communications

188 Editorial Comment

191 Book Reviews

Office of publication: Curtis Reed Plaza, Menasha, Wisconsin.

Foreign Agent: P. S. King and Staples, Ltd., Great Smith Street, Westminster, London.

Second class postage paid at Washington, D.C., and at additional mailing offices.

Printed in the United States of America by George Banta Company, Inc., Menasha, Wisconsin.

Copyright, 1972, by The American Political Science Association 


\section{ARTICLES}

11 Where the Votes Come From: An Analysis of Electoral Coalitions, 1952-1968. This paper describes how the contributions that different groups make to a party's total strength can be specified by breaking down each contribution into its three components-size, turnout, and loyalty. Through the use of survey data on reported vote rather than party identification, the voting coalitions of the Democrats and Republicans are analyzed. By means of examples of selected groups, the actual magnitude of these contributions and their components are presented for each of the last five presidential elections. Major attention is given to a group-by-group evaluation of the generally accepted view that the Democrats are a coalition of diverse overlapping minorities including the poor, Blacks, union members, Catholics and Jews, Southerners, city dwellers and perhaps the young; and the view that the Republicans have appeal for the corresponding nonminorities. The empirical results show which aspects of these views are valid and which are not. Some implications for the party system as well as the strategic considerations inherent in this approach are also discussed.

By Robert Axelrod, Assistant Professor of Political Science, University of California, Berkeley

21 Turnout and Representation in Presidential Primary Elections. This paper provides a partial test of the widely-held assumption that preference primaries are the most representative element of the presidential nominating system. It notes that the average voting turnout in presidential primaries is only 39 per cent, compared with 69 per cent in the same states' ensuing general elections. The representative quality of these electorates is examined with data from sample surveys of the 1968 New Hampshire and Wisconsin primaries. A comparison of the primary participants with nonparticipants among each party's identifiers shows, first, that presidential primary electorates are demographically unrepresentative of their nonvoting fellow partisans in age, education, income, and social status. Second, primary participants have no more intense party identifications than do nonparticipants. Third, participants hold issue positions more strongly than nonparticipants do, and on some issues they even hold positions contrary to those of nonparticipants. Finally, both of the Democratic primaries overrepresented Johnson sentiment and underrepresented McCarthy and Kennedy sentiment. The author concludes that the preference primaries' claim to be the most representative element of the presidential nominating system may not be warranted, especially if and when the national conventions are reformed along lines such as those laid down by the McGovernFraser Commission. In any case, 1972 offers a unique opportunity to study the comparative representativeness of local, state, and national party conventions and the preference primaries.

By Austin Ranney, Professor of Political Science, The University of Wisconsin, Madison

38 Decision Making in Soviet Cities. How are decisions made in Soviet cities? Who are the municipal decision makers? What kinds of decisions do they make? Is there a Soviet urban political system? This article attempts to answer these questions by focusing on four aspects of decision making in Soviet cities: budget formulation, the planning process, housing construction and allocation, and the staffing of key municipal posts.

Urban autonomy has increased in the past decade, but Soviet municipalities are very much restricted in their decision making. Superior Party and governmental authorities continue to dominate the decision-making process and any decision made by municipal authorities can be vetoed by superior Party and governmental organs.

Soviet municipal decision making is now being influenced by three tendencies: municipal administrators are acquiring more influence in municipal government and administration; the educational qualifications and professional expertise of city Party members are rising; ad hoc citizen and group interest articulation may be developing. Comparisons between Soviet and North American urban decision-making models are useful and valid, although they require an improved methodology and much more Soviet data.

By B. Michael Frolic, Associate Professor of Political Science, York University.

53 Interest Groups and Political Integration: British Entry into Europe. This article analyzes the influence of interest groups in the formation of British policy toward participation in European unity From the important theoretical literature bearing on the subject, it derives and tests two hypotheses relating group behavior to the political integration process. The hypothesis imputed to the group politics approach holds that if interest groups influence policy formation, then progress toward 
integration is likely to be impeded. The hypothesis suggested by an extension of the functionalist approach implies that if interest groups influence policy formation, then progress toward integration is likely to be facilitated. The data indicate a confirmation of the first hypothesis and a rejection of the second. Groups were unfavorable toward European unity for both organizational and economic reasons. They restrained Britain's movement toward participation in integrated European ventures until the onset of effective politicization. Then the introduction of broadly conceived national interest considerations displaced cost-benefit calculations as the criteria for judgment and diminished the groups' influence. At least in the task of enlarging a geographic area of integration, if not in expanding that integration once a grouping already exists, a conscious political decision was found to be essential.

By Robert J. Lieber, Assistant Professor of Political Science, University of California, Davis.

68 Political Clientelism and Ethnicity in Tropical Africa: Competing Solidarities in Nation-Building. The concept of political clientelism is one if the few genuinely crosscultural concepts available to political scientists for the comparative study of transitional systems. As a descriptive concept, political clientelism helps us uncover patterns of relationships which deviate markedly from those ordinarily associated with class or ethnicity. As an analytic concept political clientelism provides crucial insights into the internal dynamics of social and political change. Moreover, if, as some contend, patterns of resource allocation are more meaningful indicators of political development than their conceptual opposites, political clientelism may well supply the critical "missing link" between micro- and macro-sociological or system-centered theories of political development.

By René Lemarchand, Professor of Political Science, University of Florida.

91 Patron-Client Politics and Political Change in Southeast Asia. The analysis presented here is an effort to elaborate the patron-client model of association, developed largely by anthropologists, and to demonstrate its applicability to political action in Southeast Asia. Inasmuch as patron-client structures are not unique to Southeast Asia but are much in evidence, particularly in Latin America, in Africa, and in less developed portions of Europe, the analysis may possibly have more general value for understanding politics in preindustrial societies. After defining the nature of patronclient ties and distinguishing them from other social ties, the paper discriminates among patronclient ties to establish the most important dimensions of variation, examines both the survival and transformations in patron-client links in Southeast Asia since colonialism and the impact of major social changes such as the growth of markets, the expanded role of the state, and the creation of local regimes. Finally, the paper shows how patron-client bonds interact with electoral politics to create distributive pressures which, in turn, often lead to inflationary fiscal policies and vulnerability of regimes to losses of revenue.

By James C. Scotr, Associate Professor of Political Science, University of Wisconsin.

114 On Anarchism and the Real World: William Godwin and Radical England. Much that is characteristic of contemporary anarchist thought can be found in the writings of the founder of that tradition, William Godwin. He is ambivalent on the value of technology and modernity, nostalgic at one moment and progressive another. He extols individual autonomy while preaching community solidarity. Above all he shares with modern anarchism an elitist disdain for ordinary men and women, which in the case of Godwin leads to an unresolved tension between theoretical radicalism and practical conservatism. His anarchist doctrine repudiates all forms of coercion, law, and government. It eschews cooperation of all kind as deleterious to individual development. At the same time it posits an ideal order characterized by a high degree of informal coercion practiced by zealous neighborly inspection. But Godwin was a less than eager friend of reform and agitation during the years of Pitt's repression of radical movements in England. This was clear even in the pages of Political Justice, but all the more obvious in his feud in 1795-96 with John Thelwall and the London Corresponding Society, the leading radical activists. This paper outlines Godwin's anarchism and points out the implications of his dispute with Thelwall. In addition it shows the extent to which Godwin has given anarchism certain of its enduring qualities.

By Isaac Kramnick, Associate Professor of Political Science, Yale University.

129 Congress and the Defense Budget: 1960-1970. It is commonly held that Congress has made only inconsequential changes in the President's requests for defense appropriations. Scholarly studies of 
the budgetary process, notably the work of Fenno and Wildavsky, do not include defense spending in their analyses. For nondefense spending they find that Congress has primarily a fiscal rather than programmatic orientation toward appropriations.

House and Senate changes in the President's defense appropriations requests were analyzed for the fiscal years 1960 through 1970. It was found that small Congressional changes in total defense spending obscured more substantial activity in particular budget categories. The concentration of Congressional activity in two of these categories-Procurement and R\&D-indicates that Congress has had a significant programmatic orientation toward defense spending. Changes in the level of Congressional activity across time confirm this hypothesis.

Efforts to measure the relative influence of the House and Senate proved inconclusive. The Senate dominated the conference committee, but the Senate's influence was concentrated in the least important budget categories. The House made most of the changes in the President's budget requests, but very few of such changes were appealed by the Defense Department to the Senate.

By Arnold Kanter, Assistant Professor of Political Science, The Ohio State University.

144 A Theory of Political Ambition: Career Choices and the Role of Structural Incentives. Officeholders periodically face the problem of choosing among a set of career alternatives, and these alternatives customarily include the choice of dropping out of political life, or seeking reelection, or of choosing to seek higher office. This paper assumes that officeholders behave according to a rational calculus in making such choices, and that the main elements involved in the choice process include the probabilities and values attached by the candidate to his alternatives, and the investments required to obtain these alternatives. Political ambition, or the desire to seek higher office, is shown to develop as a product of the investments that politicians make in their political careers, and the investments are shown to be associated with the structural characteristics of community size and electoral competitiveness. The subjects of the research are 435 city councilmen from 89 cities of the San Francisco Bay Region, and the data include information derived from interviews with the councilmen and aggregate election data collected on each city.

By Gordon S. Black, Assistant Professor of Political Science, University of Rochester.

160 The Committee Function: An Influence Equation. In legislative systems a bill is commonly considered and reported by an appropriate committee before it is considered on the floor of the house. Since motions on the floor frequently relate to such bills, it is often apposite to refer to a motion's relevant committee. This article presents a mathematical model of the relationship between the relevant committee's divisions on the floor and a motion's probability of passing. Let $\mathrm{x}$ be the proportion of the relevant committee voting yea on the floor, $z$ be the proportion of the relevant committee voting nay on the floor, and $y$ be the proportion of the relevant committee neither voting yea nor voting nay on the floor, then a motion's probability of passing is $\left(x^{2}+y^{2}\right) /\left(x^{2}+\right.$ $y^{2}+z^{2}$. The fit between theory and observation is quite good: six hundred eleven roll calls from the 90 th and 91 st Congresses have been analyzed; 0.628 of the motions actually passed; and 0.613 of the motions were expected to pass.

By Thomas W. Casstevens, Associate Professor of Political Science, Oakland University.

164 APSA Presidential Address: To Nurture a Discipline. Discipline based associations have gone through two stages: "learned society" and "professional association." Because of the inadequacies of the market for ideas and talent, it is time for a third stage or model, "science management." Certain characteristics of the discipline affect the utility of this model, including the level of training (relatively modest), the resources available to the discipline (lower than other social sciences), and disciplinary morale and cohesion (relatively high).

There has been an increase in doctoral programs in political science at the rate of about three new programs per year for the past twelve years. Many of these new programs are of doubtful quality, but they may be useful to the discipline in terms of teacher training (although less useful for research training), if their doctorates replace persons with the master's degree, and if they add to, rather than substitute for, a full complement of persons trained by the older quality programs. Regionalization of doctoral programs is opposed, and some characteristics of quality programs are stated: relatively large faculties and student enrollments, and high proportions of research oriented full professors. Discipline wide enrollment policies should be from "the top down" in terms of quality of the programs.

Creative political science can be identified and encouraged by attention to its constituent elements, conditions, and the selection of students identified by measures of creative potential. Creative research productivity is more related to motivation than to intelligence (beyond a certain level); a productive research career is directly and strongly related to the quality of a 
person's graduate program and the quality of his employing institution, as well as to the eminence of his dissertation sponsor. Individual and collective research productivity has increased; the consequent information explosion requires more systematic information exchange and a policy of encouraging the most fruitful research agendas for the discipline.

By Robert E. LANe, Professor of Political Science, Yale University.

From Gerald H. Kramer, Theodore S. Arrington, David Nexon, W. Scott Thompson, Douglas W. Rae and Michael Taylor, Kenneth A. Shepsle.

\section{BOOK REVIEWS}

191 Political Theory, History of Political Thought and Methodology

Black, Monarchy and Community: Political Ideas in the Later Conciliar Controversy, 1430-1450. Paul E. Sigmund, p. 191

Hobbes, A Dialogue Between a Philosopher and a Student of the Common Laws of England (edited by Joseph Cropsey). J. Roland Pennock, p. 192

Jorrín and Martz, Latin American Political Thought and Ideology. Edward J. Williams, p. 193

Kruskal, ed., Mathematical Sciences and Social Sciences. Oliver Benson, p. 194

\section{American Government and Politics}

Adams, The Growing Church Lobby in Washington. R. Wallace Brewster, p. 195

Beck, ed., Law and Justice: Essays in Honor of Robert S. Rankin. John R. Schmidhauser, p. 196

Bollens, Bayes and Utter, American County Government: With an Annotated Bibliography. Samuel K. Gove, p. 197

Burton, Democrats of Oregon: The Pattern of Minority Politics 1900-1956. Lester G. Seligman, p. 198

Domhoff, The Higher Circles: The Governing Class in America. Earl Latham, p. 199

Feingold, The Politics of Rescue: The Roosevelt Administration and the Holocaust, 1938-1945. Morton J. Tenzer, p. 201

Fitch and Walsh, eds., Agenda for a City: Issues Confronting New York. Andrew Hacker, p. 203

Haveman and Margolis, eds., Public Expenditures and Policy Analysis. Walter G. Held, p. 204

Hinckley, The Seniority System in Congrtss. George Goodwin, Jr., p. 205

James, The Years of MacArthur. Vol. 1: 1880-1941. Dale Pontius, p. 206

Kurland, ed., Felix Frankfurter on the Supreme Court: Extrajudicial Essays on the Court and Constitution. D. S. Hobbs, p. 207

Lindbergh, The Wartime Journals of Charles A. Lindbergh. Alexander DeConde, p. 208

Marcus, Grand Old Party: Political Structure in the Gilded Age, 1880-1896; and Yearley, The Money Machines: The Breakdown and Reform of Governmental and Party Finance in the North, 1860-1920. Hugh Douglas Price, p. 210

Merelman, Political Socialization and Educational Climates: A Study of Two School Districts. Pauline Marie Vaillancourt, p. 211

Navasky, Kennedy Justice. Nelson W. Polsby, p. 212

Nimmo and Oden, The Texas Political System; and Anderson, Murray and Farley, Texas Politics: An Introduction. Joseph L. Bernd, p. 214

Ries, Executives in the American Political System. Lloyd A. Rowe, p. 215

Russett, What Price Vigilance? The Burdens of National Defense. Kenneth E. Boulding, p. 217

Tyler, The Political Imperative: The Corporate Character of Unions and The Labor Revolution. Melvin A. Kahn, p. 218

Wasby, The Impact of the United States Supreme Court: Some Perspectives. Twiley W. Barker, p. 220

Wright, Federal Grants-in-Aid: Perspectives and Alternatives. Parris N. Glendening, p. 221

\section{Comparative Government and Politics}

Allen and Johnson, eds., African Perspectives: Papers in the History, Politics, and Economics of Africa Presented to Thomas Hodgkin. Sheldon Gellar, p. 222

Anderson, The Nordic Council: A Study of Scandinavian Regionalism. Joseph B. Board, p. 223

Backer, Priming the German Economy. F. A. Breier, p. 225

Chao, Agricultural Production in Communist China 1949-1965. Ramon H. Myers, p. 226 
Cohn, Economic Development in the Soviet Union. A. Nove, p. 227

Crowder and Ikime, West African Chiefs: Their Changing Status Under Colonial Rule and Independence. Lloyd A. Fallers, p. 228

de Robien, The Diary of a Diplomat in Russia, 1917-1918; Kenez, Civil War in South Russia, 1918; and Silverlight, The Victors' Dilemma: Allied Intervention in the Russian Civil War, 1917-1920. Robert F. Byrnes, p. 229

Gamarnikow, Economic Reforms in Eastern Europe. Robert Owen Freedman, p. 231

Gann and Duignan, eds., Colonialism in Africa 1870-1960. Volume Two: The History and Politics of Colonialism 1914-1960. Harvey Glickman, p. 232

Gordon, Self-Determination and History in the Third World. Rupert Emerson, p. 233

Green, The Containment of Latin America: A History of the Myths and Realities of the Good Neighbor Policy; and Duncan and Goodsell, eds., The Quest for Change in Latin America: Sources for a Twentleth Century Analysis. Alexander Edelmann, p. 235

Groennings, Kelley and Leiserson, eds., The Study of Coalition Behavior: Theoretical Perspectives and Cases from Four Continents. Steven J. Brams, p. 236

Havens and Flinn, eds., Internal Colonialism and Structural Change in Colombia, Reid R. Reading, p. 238

Hazard, Communists and Their Law: A Search for the Common Core of the Legal Systems. of the Marxian Socialist States. Harold J. Berman, p. 240

Hill, God's Englishman: Oliver Cromwell and the English Reoolution; and Breen, The Character of the Good Ruler: A Study of Puritan Political Ideas in New England, 1630-1730. Michael Walzer, p. 241

Hilliker, The Politics of Reform in Peru: The Aprista and Other Mass Parties of Latin America. Edward C. Epstein, p. 242

Johnson, The Cameroon Federation: Political Integration in a Fragmentary Society. Claude E. Welch, Jr., p. 243

Journalist M., A Year is Eight Months; and Sviták, The Czechoslovak Experiment, 1968-1969. Joseph Hajda, p. 244

Kochan, ed., The Jews in Soviet Russia Since 1917. John A. Armstrong, p. 246

Kornberg and Musolf, eds., Legislatures in Developmental Perspective. Hans H. Baerwald, p. 248

Kumar, Essays on Gandhian Politics; The Rowlatt Satyagraha of 1919. Joan V. Bondurant, p. 249

Leach and Mukherjee, eds., Elites in South Asia. Theodore P. Wright, Jr., p. 251

Levinson and Brightman, eds., Venceremos Brigade: Young Americans Sharing the Life and Work of Revolutionary Cuba; and Reckord, ¿ Does Fidel Eat More Than Your Father?: Conversations in Cuba. Patricia W. Fagen, p. 252

Loomis and Rytina, Marxist Theory and Indian Communism. John Patrick Haithcox, p. 254

Malloy, Bolivia: The Uncompleted Revolution. Robert D. Tomasek, p. 255

Mboya, The Challenge of Nationhood: A Collection of Speeches and Writings. Brack Brown, p. 257

Moine, Résultats des élections belges entre 1847 et 1914. Val R. Lorwin, p. 258

Myrdal and Kessle, China: The Revolution Continued; and Hsiung, Ideology and Practice: Evolution of Chinese Communism. Pi-chao Chen, p. 259

Nagy-Talavera, The Green Shirts and the Others: A History of Fascism in Hungary and Rumania. Randolph L. Braham, p. 261

Petrov, Mongolia: A Profile. Paul Hyer, p. 262

Powell, Social Fragmentation and Poltical Hostility: An Austrian Case Study. Robert D. Putnam, p. 263

Rhodes, The Government of London: The Struggle for Reform. Wallace S. Sayre, p. 264

Rivkin, Nation-Building in Africa: Problems and Prospects (edited by John H. Morrow). I. William Zartman, p. 266

Rotberg and Clague, Haiti: The Politics of Squalor. Jean-Claude Garcia-Zamor, p. 266

Ruin, ed., Scandinavian Political Studies, Volume 5/1970. Dankwart A. Rustow, p. 267

Sharp, The Ministry of Housing and Local Government. Fred Tickner, p. 269

Spencer, ed., Religion and Change in Contemporary Asia. Donald E. Smith, p. 270

Suh, Documents of Korean Communism 1918-1948. John Kie-Chiang Oh, p. 272

Tuden and Plotnicov, eds., Social Stratification in Africa. P. C. Lloyd, p. 273

Tyrmand, ed., Kultura Essays. S. L. Andreski, p. 274

Ugalde, Power and Conflict in a Mexican Community: A Study of Political lntegration. Carolyn Needleman and Martin L. Needleman, p. 274

Walter, Student Politics in Argentina: The University Reform and Its Effects, 1918-1964. Peter G. Snow, p. 276

277 International Politics, Law and Organization

Beck, Deutsch, Raup, Rose and Turnbull, The Changing Structure of Europe: Economic, Social and Political Trends. Stuart A. Scheingold, p. 277

Butler, The Soviet Union and the Law of the Sea. Kazimierz Grzybowski, p. 278

Corbett, The Growth of World Law; and Franck, The Structure of Impartiality: Examining the Riddle of One Law in a Fragmented World. Wesley L. Gould, p. 279

George, Hall and Simons, The Limits of Coercive Diplomacy: Laos, Cuba, Vietnam. George Modelski, p. 280 
Gupta, The Fulcrum of Asia: Relations Among China, India, Pakistan, and the U.S.S.R.; and Simmonds, China's World: The Foreign Policy of a Developing State. Loren W. Fessler, p. 282

Heath, Old World, New Horizons: Britain, Europe, and the Atlantic Alliance; and Calleo, The Atlantic Fantasy: The U.S., NATO, and Europe. Francis A. Beer, p. 283

Jervis, The Logic of Images in International Relations. Paul Kecskemeti, p. 285

Ogley, The Theory and Practice of Neutrality in the Twentieth Century. Urs Schwarz, p. 286

Šeics, Small Nation Survival: Political Defense in Unequal Conflicts. Carsten Holbraad, p. 287

Thorp, The Reality of Foreign Aid. Doris A. Graber, p. 288

Toscano, Designs in Diplomacy: Pages from European Diplomatic History in the Twentieth Century (edited by George A. Carbone). Norman Kogan, p. 289

Tung, China and the Foreign Powers: The Impact of and Reaction to Unequal Treaties. Samuel Shih-Tsai Chen, p. 290

Váli, Bridge Across the Bosporus: The Foreign Policy of Turkey. Carl M. Dibble, p. 291

Van Ness, Revolution and Chinese Foreign Policy: Peking's Support for Wars of National Liberation. Shaochuan Leng, p. 293 


\title{
The American Political Science Association
}

\author{
1527 New Hampshire Ave. N.W., Washington, D.C.
}

President: HeInz EuLau, Stanford University; President-Elect: RoBerT E. WarD, University of Michigan; Vice Presidents: ROBERT MARTIN, Howard University; CLARA Penniman, University of Wisconsin; JosePh TANenhaus, State University of New York, Stony Brook; Secretary: Thomas R. DYe, Florida State University; Treasurer: Donald R. Matrhews, The Brookings Institution; Program Chairman: DwaINe MARvick, University of California, Los Angeles; Executive Director: EvRoN M. KIRKPATRICK, 1527 New Hampshire Avenue, N.W., Washington, D.C. 20036; Managing Editor, APSR: Nelson W. PoLSBY, University of California, Berkeley.

COUNCIL. (Above-named Officers ex officiis), 1971-1972; CHADwICK F. AlgER, Ohio State University; PhIlIP E. Converse, University of Michigan; Fred I. GreensteIN, Wesleyan University; JoYCe M. MITChelL, University of Oregon; James W. Prothro, University of North Carolina; William P. Robinson, SR., Norfolk State College; DaNkwarT A. Rustow, CUNY (Brooklyn); Gordon Tullock, Virginia Polytechnic Institute. 1972-1973: CHRISTIAN BAY, University of Alberta; SAMUEl DuboIs COOK, Duke University; ValerIe Earle, Georgetown University: RICHaRd F. FenNo, University of Rochester; Robert O. KeOHANE, Swarthmore College; Samuel Krislov, University of Minnesota; Gerhard LeowenberG, University of Iowa; KenNeth PREwTT, University of Chicago.

FORMER PRESIDENTS: Frank J. Goodnow, Albert Shaw, Frederic N. Judson, JAmes Bryce, A. Lawrence Lowell, Woodrow Wilson, Simeon E. Baldwin, Albert Bushnell Hart, W. W. Willoughby, John Bassett MoOre, ERnest Freund, Jesse Macy, Munroe Smith, Henry Jones Ford, Paul S. Reinsch, Leo S. Rowe, William A. Dunning, Harry A. Garfield, James W. Garner, Charles E. Merriam, Charles A. Beard, William B. Munro, Jesse S. Reeves, John A. Fatrlie, BenJamin F. Shambaugh, Edward S. Corwin, Willitam F. Willoughby, Isidor Loeb, Walter J. Shepard, Francis W. Coker, Arthur N. Holcombe, Thomas Reed Powell, Clarence A. Dykstra, Charles Grove Haines, Robert C. Brooks, Frederick A. Ogg, William Anderson, Robert E. Cushman, Leonard D. White, John M. Gaus, Walter F. Dodd, Arthur W. Macmahon, Henry R. Spencer, Quincy Wright, James K. Pollock, Peter H. Odegard, Luther H. Gulick, Pendleton Herring, Ralph J. Bunche, Charles McKinley, Harold D. Lasswelr, E. E. SchattSchneider, V. O. Key, JR., R. Taylor Cole, Carl B. Swisher, EmmetTe S. Redford, Charles S. Hyneman, Cari J. Friedrich, C. Herman Pritchett, David B. Truman, Gabriel A. Almond, Robert A. Dahl, Merle Fainsod, David Easton, Kari W. DeUTSCh, RoBert E. LANE.

\section{The American Political Science Review}

Department of Political Science, University of California, Berkeley 94720

EDTTORIAL BOARD: Nelson W. Polsby, Managing Editor, University of California, Berkeley; Philf Stegerman, Book Review Editor, San Francisco State College; Shlomo Avineri, The Hebrew University of Jerusalem; David Braybrooke, Dalhousie University; RICHARD A. BRODY, Stanford University; EDITH T. CARPER, The Aerospace Corporation; SAMUel D. CooK, Duke University; S. Rufus Davis, Monash University; ROBERT C. FRIED, University of California, Los Angeles; ARTHUR S. GOLDBERG, University of Rochester; MORTON H. HALPERIN, The Brookings Institution; NANNerl O. Keohane, Swarthmore College; PeTER LASLetT, Trinity College, Cambridge University; RUSSELl D. MURPHY, Wesleyan University; WALTER F. MURPHY, Princeton University; JOAN M. NELSON, Woodrow Wilson International Center for Scholars; H. Douglas PrICE, Harvard University; RoBerT D. PUTNAM, University of Michigan; Douglas W. RaE, Yale University; Austin RANNEY, University of Wisconsin; GroVANNI SaRTori, University of Florence; MICHAEL J. ShapIRo, University of Hawaii; Paul Sniderman, University of Toronto; StePhen V. Stephens, The Johns Hopkins University; GEORGE E. VoN DER MUHLL, University of California, Santa Cruz; RICHARD A. WATSON, University of Missouri. MANUSCRIPT EDITOR: ELLEN Y. SiEgeLman. EDITORIAL ASSistants: Margaret Carlson, Barbara Hight, Norma minor. EDITORIAL INTERNS: Steven Blutza, Gerald Clayton, Dorothy Clayton, Craig Garrett, Yvonne Jones, Beverly Kearns, Sam Kernell, David lattin, William M. Lunch, Jesse McCorry, Dan Metlay, Robert Nakamura, alex Radian, Byron Shafer, Jay Staring, Harry Williams. 
The American Political Science Review, published quarterly during the months of March, June, September, and December, is supplied to all APSA members. Membership dues are charged according to the following schedule:

$\begin{array}{lr}\text { Membership Category } & \text { Dues } \\ \text { Regular } & \\ \text { Annual income } & \$ 20 \\ \text { Under } \$ 12,000 & \$ 25 \\ \$ 12,000-\$ 15,000 & \$ 30 \\ \text { Over } \$ 15,000 & \$ 10 \\ \text { Student and Retired } & \$ 5 \\ \text { Family } & \$ 1000 \\ \text { Life } & \$ 35\end{array}$

Student memberships are limited to five years per person. Foreign currency at the official exchange rate will be accepted for foreign subscriptions and foreign membership fees. The equivalent of $\$ 1$ for additional postage should be added for foreign subscriptions.

Current issues are priced at $\$ 7.50$ per copy; for back issues prior to 1968 address Johnson Reprint Corp., 111 5th Ave., New York, N.Y. 10003; for issues 1968 and later send request directly to the American Political Science Association.

Applications for membership, orders for the Review, and remittances should be addressed to the Executive Director, The American Political Science Association, 1527 New Hampshire Ave., N.W., Washington, D.C. 20036. Notices of changes of address should be received in the Washington office by the 25 th day of the months before publication.

\section{INSTRUCTIONS TO CONTRIBUTORS}

Address correspondence about contributions to the Review to Nelson W. Polsby, Department of Political Science, University of California, Berkeley, Berkeley, California 94720. Each manuscript should be accompanied by an abstract of up to 200 words briefly describing the article's contents. All manuscripts and abstracts should be submitted IN DUPLICATE. They should be doublespaced and may be in typed, mimeographed, hectographed, or other legible form. Footnotes should appear at the end of the manuscript, not at the bottom of the page, and should also be doubled-spaced. Manuscripts that do not follow this format will be returned to the authors for retyping.

Since manuscripts are sent out anonymously for editorial evaluation, the author's name and affiliations should appear only on a separate covering page. All footnotes identifying the author should also appear on a separate page.

Address books intended for review to Philip Siegelman, American Political Sctence Review, 210 Barrows Hall, University of Cálifornia, Berkeley, Berkeley, California 94720. Information, including News and Notes, for the Association's newsletter, PS, should be sent to 1527 New Hampshire Avenue, N.W., Washington, D.C. 20036; advertising, reprint and circulation correspondence should be sent to the Executive Director at the Washington office. Advertising information and rates are available from Jeanne Mozier, Adv. Manager, APSA, 1527 New Hampshire Avenue, N.W., Washington, D.C. 20036.

Articles and notes appearing in the Review before the June, 1953 issues were indexed in The Reader's Guide to Periodical Literature. The International Political Science Abstracts and the Social Sciences and. Humanities Index current issues. Microfilm of the Review, beginning with Volume 1, may be obtained from University Microfilms, 313 North First Street, Ann Arbor, Michigan 48106. A Cumulative Index of the Review, Volumes 1-62: 1906-1968, may also be obtained from University Microfilms. Articles appearing in the Review are listed regularly in ABC Pol Sci and Current Contenis: Behavional, Social \& Management Sciences. 


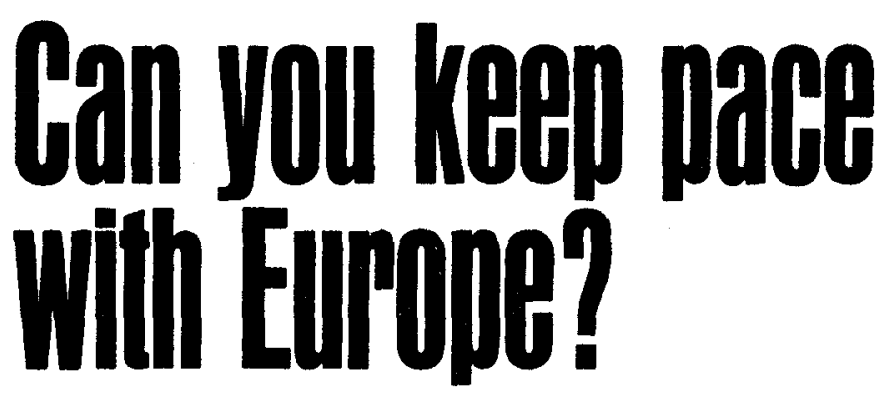

Big changes are taking place in the European Community as ...

EULAREMEIT transforms the political map of Europe MSTIIUIIU!S evolve to meet

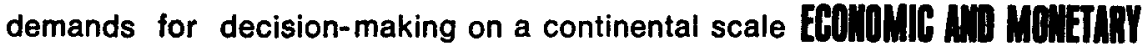
VIII.I takes shape and a course is set for a European currency LFA|SUIIII, responds to the new social and economic needs of Europe TRIDE to and from Europe dominates world commerce COMMOI. PROALEMS challenge the US and Europe to find common solutions

We don't claim to know everything that is going to happen. But we usually are the first to know when important changes do occur in the European Community. We want to share our knowledge with you, especially now that the Community is expanding from six to ten.

It you are interested in more facts and information,

Write or telephone the European Community Intormation Service for:

\section{Publications}

- there are titles available dealing with all aspects of Community Affairs.

Official Documents

in the four Community languages (some available in English).

Lecture and Conference Service

for academic groups.

Periodic Publications

-there are more than 25, monthly and quarterly. Some by subscription, some free.

Complete Library and Reference Service

for Economic, Technical and Trade Information and Statistics. Telephone in-

quiries welcomed.

Background Notes

on current Community issues and problems.

Films and Tapes

for conferences and seminars.

Exhibits

and exhibit materials for conferences and conventions.

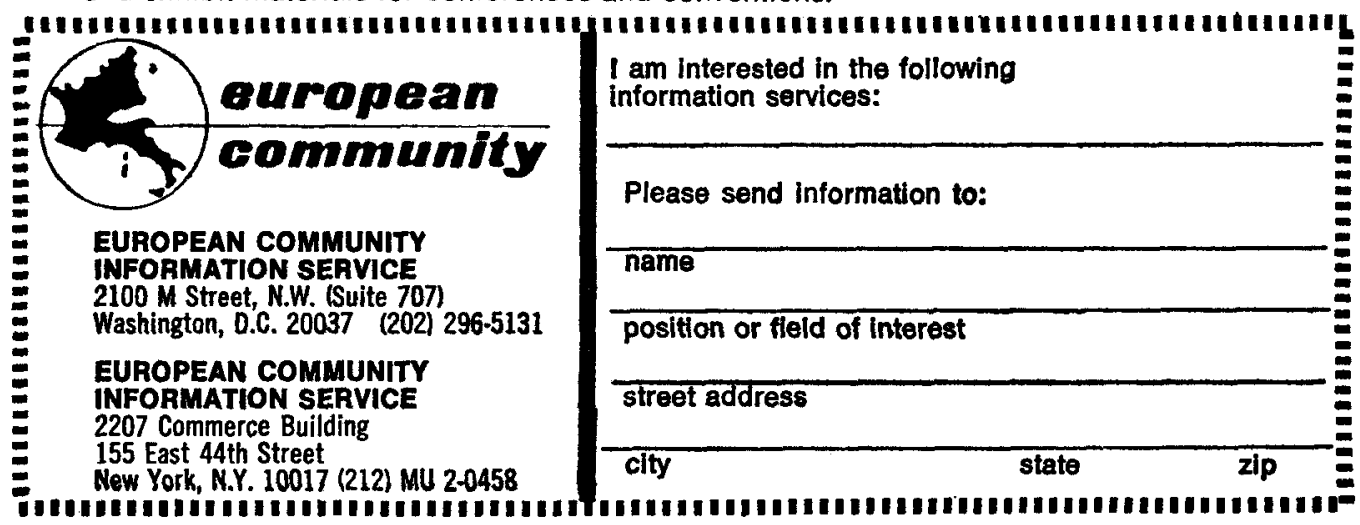

Please mention The Am.erican Political Science Review when writing to advertisers 